\title{
MAX PLANCK INSTITUTE
}

FOR COMPARATIVE PUBLIC LAW

AND INTERNATIONAL LAW

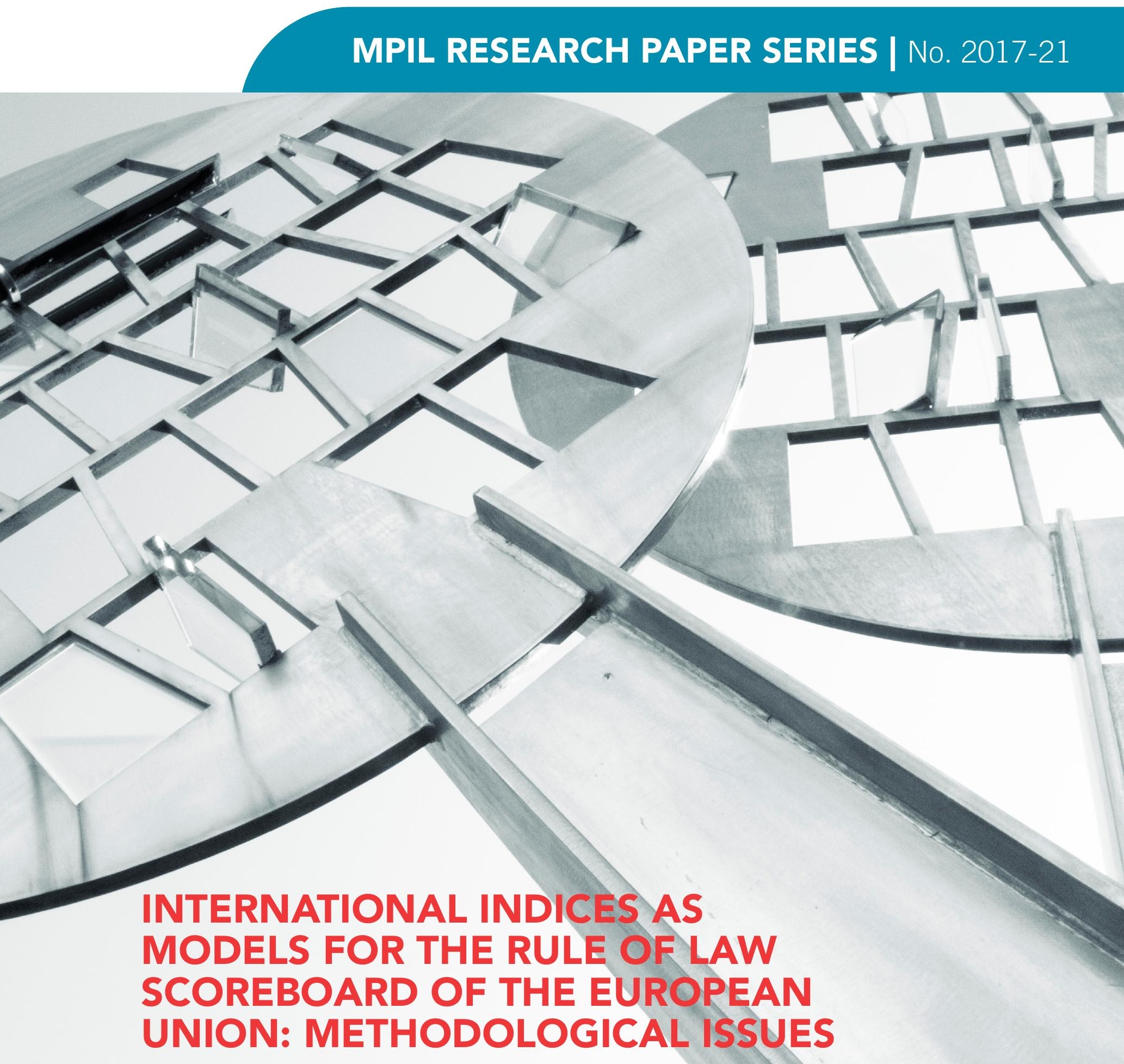

András Jakab, Viktor Lőrincz 


\title{
MAX PLANCK INSTITUTE
}

FOR COMPARATIVE PUBLIC LAW

AND INTERNATIONAL LAW

MPIL RESEARCH PAPER SERIES

No. 2017-21

\section{INTERNATIONAL INDICES AS MODELS FOR THE RULE OF LAW SCOREBOARD OF THE EUROPEAN UNION: METHODOLOGICAL ISSUES}

\author{
AUTHORS \\ András Jakab, Viktor Lőrincz \\ EDITORIAL DIRECTORS \\ Armin von Bogdandy, Anne Peters \\ EDITOR-IN-CHIEF \\ Steven Less \\ TECHNICAL ASSISTANCE \\ Verena Schaller-Soltau \\ Angelika Schmidt \\ STUDENT ASSISTANT \\ Eda Oez
}




\section{ABSTRACT}

Since the early 2010s, and especially since the 10 June 2015 resolution of the European Parliament, there has been a growing interest in monitoring and measuring the rule of law in the Member States of the EU. Going beyond the available measurement tools in Europe, such as the EU Justice Scoreboard, we discuss the lessons taught by the construction of international indices on the rule of law. In addition to the traditional toolbox of a lawyer, we have to turn to other methods of social sciences and statistics in order to quantify the state of, as well as the changes and trends in the rule of law. The methodology regarding this topic has an extensive literature and we can enumerate manifold indices measuring the rule of law for example from Europe or from the United States (e.g. Freedom House, Bertelsmann Stiftung, World Bank, World Justice Project) The present paper is an introduction to the methodology in which we focus on the terminology, the collection and aggregation of data, the interpretation of the results and the comparison within the countries and over time, by these indices as possible precursors of a future EU scoreboard on the rule of law.

\section{KEYWORDS:}

European Scoreboard of Rule of Law, international indices, Freedom in the World, Bertelsmann Transformation Index, Worldwide Governance Indicators, World Justice Project, Rule of Law Index, conceptualisation, law \& statistics, measuring legal systems, empirical methodology 
András Jakab - Viktor Lőrincz

International Indices as Models for the Rule of Law Scoreboard of the European Union: Methodological Issues

\section{Introduction: Toward a European Scoreboard of Rule of Law?}

From time to time, in the European public discourse, a need for a mechanism based on quantitative data concerning the rule of law in the Member States is addressed. Some proposals discuss the use of statistics conceived for another objective, like the EU Justice Scoreboard, where the aim is to measure quality, efficiency and independence of justice in the Member States of the EU. ${ }^{1}$ Other authors suggest a new scoreboard, on the basis of the existing scoreboards, like the abovementioned EU Justice Scoreboard, or the EU Anti-Corruption report, augmented by other sources of data. $^{2}$

These measurement tools cover only a part of the whole notion of the rule of law. Therefore, we turn to other tools: international indices. We do this in order to discuss the methodology of these tools as a possible prefiguration for an EU Scoreboard on the Rule of Law.

We agree with Bárd et al., if the EU wants to establish legal procedure or sanctions based on the outcome of the intended scoreboard, this scoreboard cannot be "contracted out" to international organisations. ${ }^{3}$ On the one hand, as we will see, some of the existing international indices are biased in favour of a given form of government or market economy. On the other hand, as Versteeg and Ginsburg have pointed out, ${ }^{4}$ there is a high correlation between these indices; therefore, it is questionable whether the establishment of a European index based on a brand new methodology is necessary or even possible.

Because of the complex character of these indices, and because of the methodological doubts to be described below, an automatized mechanism initiated by the reaching of a given level of violations, for example, is less imaginable. A future EU Rule of Law Scoreboard should rather work as an aid for decision making.

\section{Why Measure Legal Systems?}

In the literature, we find numerous indices on the legal system. ${ }^{5}$ This fact has several reasons: 1) One single indicator can sum up easily complicated questions, ${ }^{6}$ so that the non-professionals and the press can also use it. ${ }^{7}$ We should not underestimate this explanatory character, because it is also a

\footnotetext{
${ }^{1} \mathrm{http}: / /$ ec.europa.eu/justice/effective-justice/files/justice_scoreboard_2016_en.pdf see for instance https://www.opensocietyfoundations.org/voices/justice-scoreboard-effective-mechanism-enforce-respect-rulelaw and https://www.opensocietyfoundations.org/sites/default/files/how-monitor-rule-law-democracy-andfundamental-rights-eu.pdf

${ }^{2}$ On benchmarking especially: (Bárd et al. 2016, 24-28), the authors also quote the need for annual monitoring according to the European Parliament resolution of 10 June 2015 on the situation in Hungary (2015/2700(RSP)): (Bárd et al. 2016, 10)

3 (Bárd et al. 2016, 11)

4 (Versteeg and Ginsburg 2016)

5 Observing the increasing number of indices, some authors speak about an "indicator fatigue" (Hammergren 2015 esp. p. 311) For advice on terminology and content, we would like to express our gratitude to Mátyás Bencze, György Gajduschek, András Jóri, Márton Medgyesi, Ákos Szalai and Balázs Váradi. The general methodological summary and the analysis of the rule of law-indices is the work of András Jakab, the Doing Business part and the English adaptation was made by Viktor Lörincz.

${ }^{6}$ (Saisana and Saltelli 2011) 247-268, esp. 248.

${ }^{7}$ This is also dangerous, because the measured value also can impact reality, for example, measuring high level of corruption can boost the acceptability of corruption and by doing so, it can also increase real corruption. See (Ginsburg 2011) 270: "Perceptions can produce their own reality”, 279: ,a bad image can become a selffulfilling prophecy".
} 
tool of democratic accountability. 2) Indices are also often considered as external measures in debates about legal interpretation (evaluating reforms or the performance of the government), they can also set goals and directions of policies. ${ }^{8}$ Because of this, international organisations and NGOs also use indices in order to foster and propagate best practices by comparing points of different countries. Exemplary countries usually score at the top of the scale set up by these organisations. ${ }^{9}$ A side-effect of this approach is the case when for example a government changes policy only to change the score on a scale, without treating the real problem. ${ }^{10} 3$ ) Finally, economists need quantitative data in order to test political-economical correlation (for example between the rule of law and economic performance). ${ }^{11}$

The problem is that we want to measure a directly unobservable phenomenon (rule of law for example). ${ }^{12}$ Fortunately, statistics has several methods to handle this, and in the next chapters, we will present this approach for lawyers, without entering into the mathematical details. We focus on the measurement of the rule of law, but the fundamental methodological problems are similar in the case of other legal systems too. ${ }^{13}$

Measuring and quantification is not part of the traditional toolbox of a lawyer, ${ }^{14}$ and the attitude of lawyers toward statistical methods is also ambiguous. Sometimes, they underestimate the indices because of the extent of simplification (or even discredit them, based on some unlikely outcomes), but they also admire the unintelligible mathematical models. In the present paper, we would like to find the golden mean between these two extreme approaches, by using the indices as important tools and as additional information for the better understanding of the overall view, treating them with precaution and critics.

A remark on terminology: we mean by Indicator a single number or feature and by index, composite indicators. ${ }^{15}$

\section{Methodological steps}

In this chapter, we present the methodological questions based on the legal literature and on the OECD Handbook on Constructing Composite Indicators (2008). ${ }^{16}$ The main rule is that the design of the index must be transparent, and the methodological choices must be grounded, otherwise the indices can serve pre-established policies. ${ }^{17}$

First, we have to note that some steps of the index-building need thorough knowledge in legal doctrine (e.g. conceptualization), and other steps need an expertise in statistics (e.g. handling and aggregating data). As there are a few experts who excel at both fields, index-building is usually teamwork, based on the co-operation of legal experts and statisticians, even if they sometimes speak completely different languages.

\footnotetext{
${ }^{8}$ (Botero, Nelson, and Pratt 2011),esp. 153, 159-160.

9 About this problem in the practice, and concerning the question of legitimacy, see (Davis, Kingsbury, and Merry 2012, 71-104)71-104; (Bogdandy and Goldmann 2008, 241-98)241--298; (Krever 2013, 131-50)131150; (Rosga and Satterthwaie 2009, 253-315) 253-315.

${ }^{10}$ (Botero, Nelson, and Pratt 2011, 159)159. In general see: (Saltelli 2006, 65-77)65--77.

${ }^{11}$ Desrosières grouped the states in five clusters according to their methods of using indicators. In this system socialist planned economy, the mercantilism of Colbert and the France of Charles de Gaulle are in the same, engineer-state group. (Desrosières 2015) 329-353, 335-337.

12 (Kaufmann, Kraay, and Mastruzzi 2011a, 220). 220: "inherently unobservable nature"

${ }^{13}$ E.g. (Blank 2004) siteresources.worldbank.org/INTLAWJUSTINST/Resources/Benchmarking.pdf.

${ }^{14}$ Indices can be useful in the field of comparative law too, see (Michaels 2009, 765-96)765--796. But lawyers are usually cautious toward this approach. Other legal academics, linked to an underscoring system, used to emphasise the methodological shortcomings of the indices, like (Fauvarque-Cosson and Kerhuel 2009, 81130)811-830.

15 About the etymology and use of the word "indicator" see (Porter 2015,) 34--55. For a definition extended on composite values see: (Merry, Davis, and Kingsbury 2015)1--24, 4.

16 (European Commission, Organisation for Economic Co-operation and Development, and SourceOECD (Online service) 2008) 20-21; www.oecd.org/std/42495745.pdf.

17 (European Commission, Organisation for Economic Co-operation and Development, and SourceOECD (Online service) 2008)13-14.
} 


\subsection{Conceptualisation}

Before starting the construction of the index, we should clarify what we want to measure. Babbie, quoting Kaplan, classifies measurable things into three categories: 1) direct observables like mark on a questionnaire, 2) indirect observables bringing minutes of corporate board meetings as one of the examples, 3) and constructs, like the IQ, prejudice or government. ${ }^{18}$ Lawyers are chiefly familiar with the latter field. A main part of a lawyer's work is the terminological analysis. If we want to measure rule of law for example, we have to define it. The main control of these definitions is the professional public. If the majority of this public (constitutional lawyers for instance) finds the definition acceptable, the definition seems to be appropriate. ${ }^{19} \mathrm{We}$ can, of course encounter numerous terminological debates, ${ }^{20}$ for example, the concept of rule of law is not devoid of this (and because of the debates on values, we cannot expect a full consensus on this matter), ${ }^{21}$ we can use a mainstream term but with caution. Some indices also diverge concerning the definition used, we will discuss this problem later. Legal indices usually measure the de facto characteristics of a system, so a "nice" law but with a corrupt, oppressive or ineffective implementation will underscore on these scales. ${ }^{22}$

\subsection{Choosing data}

If we have already determined the thing to be measured, we have to find data for the measurement. We cannot measure the quality of a given legal system directly. Therefore, we use proxies (approximate data): the opinion of experts or that of the public (soft data) or approximate facts (hard data, i.e. the number of registered crime, the budget of the courts, frequency of the modification of law, frequency of condemnation of a State by an international court of human rights). ${ }^{23}$

The main concern about expert opinions is the choice of experts and the subjectivity of the opinion. This is an especially sensitive problem in politically polarised countries. ${ }^{24}$ As a (partial) remedy we can recommend a transparent selection method, which is also well-balanced (in a country with inter-ethnic tensions for instance, the proportion of the experts should reflect the overall ethnic distribution), or using as many experts as possible (by random sampling or with the participation of every available expert). ${ }^{25} \mathrm{~A}$ further problem is that in case of general questions (characteristic for legal indices), it is not easy to find an expert who is up-to-date in every field (for example, the criminal procedure, which is an important constituent of the rule of law, is less known for constitutional lawyers). ${ }^{26}$ In several countries, the participation implies risk for the expert too (if for example she or he criticise the current regime), even if anonymity is granted, obtaining (unbiased)

\footnotetext{
${ }_{18}^{18}$ (Babbie 2013, 168-69); (Kaplan 1964) 54-56.

${ }_{19}$ (Saisana and Saltelli 2011) 249.

20 On this phenomenon in general (lack of consensus and problems of definition in the case of composite indicators) see for example (Cherchye et al. 2007) 749-779.

21 (Botero, Nelson, and Pratt 2011) 166 quoting (Saisana and Saltelli 2011) 248: "composite indicators are value laden constructs". On the necessary political content of indices, see also (Urueña 2015) 543-584.

${ }^{22}$ As a deterrent, we can mention the Global Right to Information Rating (www.rti-rating.org), in which two NGO's analysed the state of Right to Information, but with rather surprising results: Moldova outscored the United Kingdom, and Russia performed better than the United States. Despite any disclaimer (like the implementation might differ from the written rule), it's an excellent example, how unelaborated goal-setting and conceptualisation can make indices completely useless. On the questions of conceptualisation, see also (Rottenburg 2015) 1--33, 11--18.

${ }^{23}$ (Parsons 2011) 170--185, 175-176. Proxies are used by the Social and Economic Rights Fulfilment Index (SERF) too, among other things, Right to Health Indicator is measured by the so-called age sixty-five survival rate, and the Right to Housing Indicator is measured by the access to clean water and sanitation. (Fukuda-Parr, Lawson-Remer, and Randolph 2015)59--77.

${ }^{24}$ (United Nations et al. 2011)1, see www.un.org/en/peacekeeping/publications/un_rule_of_law_indicators.pdf. In politically polarised countries, the results of the polls may vary: a popular government can increase trust in independent institutions (like the courts), and vice versa.

${ }^{25}$ (Gajduschek 2014), 110.

${ }^{26}$ On this problem, see The United Nations Rule of Law Indicators (note 25.) 24.
} 
reports will be more complicated. ${ }^{27}$ But obvious advantage of the expert opinion is that wide opinion polls are expensive, and hard data are not always available from every single country.

Using polls and surveys in the general population, we can also take into consideration the situation of vulnerable groups. The situation of these groups is less represented in expert opinions and in hard data. Survey data can also enlighten the differences between hard data and reality. ${ }^{28}$ Unfortunately, opinion surveys are expensive and the questions are limited (as the general population cannot answer very specific questions). Sampling and measurement in no-go zones and among vulnerable groups is also complicated. Public opinion is also very changable especially if it is influenced by the news. ${ }^{29}$ Another critic is the limited possibility of cross-country comparison, because of the divergent historical mentalities. ${ }^{30}$

Although the use of hard data is objective, the scope of measurement is very limited. A great part of our questions cannot be measured even by using proxy hard data (it is also possible, that something is measurable by hard data, but there is no data from a given country). We also have to be careful with available data: 1) sometimes they are corrupted by the authorities (e.g. police sometimes discourage the victims of small crimes where the success of investigation is unlikely, in order to ameliorate statistics). 2) Sometimes, the measured value only has an impact on the question in extreme cases (e.g. budget of courts on rule of law). 3) And sometimes, it is not obvious at all, whether a boost of an objective value has a positive or negative effect on the phenomenon (high efficacy of the public prosecutor can signal authoritarian judiciary tradition, and a low one can be a signal of an incompetent prosecutor) (4) And finally the partial character of the data (i.e. objective data are only available on certain special questions, not on the whole) can lead to arbitrary selection.

Some indices combine the different sources, making the results more robust (see for example the WJP-Index below), and the data sources are also cross-checked (the method is called triangulation).

\subsection{Statistical treatment and aggregation of data ${ }^{31}$}

We know different types of data: 1 or 0 (yes or no), points on a given scale ${ }^{32}$ (for instance, the experts of the Freedom House evaluate the questions on a scale ranging from 1 to 7), percentages (e.g. trust in institutions in the Eurobarometer), etc. In order to put all the data in one final index, we have to normalise (homogenise) them. ${ }^{33}$ country. ${ }^{34}$

For cross-country comparison, we have to adjust the data according to the size of the given

There are several statistical methods to handle missing data. We can, for instance, simply delete the whole row of data (i.e. if an expert answers 24 of 25 questions only, we can delete all his or her answers, or we can only leave out the unanswered question. The problem is that 1) the missing data are usually non-random (e.g. some experts are afraid of answering several questions), in this case, simply disregarding the missing answer can bias the result; 2) deleting data can also decrease the reliability of the result (that is increasing standard error). ${ }^{35}$ Therefore, if the quantity of missing data is

\footnotetext{
${ }^{27}$ The United Nations Rule of Law Indicators (note 25) 28.

${ }^{28}$ (Parsons 2011)177.

29 (Parsons 2011)178.

30 (Parsons 2011) 179.

${ }^{31}$ With this chapter, we don't want to teach lawyers how to build indices using complicated statistical methods but rather deter them from doing so. High quality work can only be done by qualified statisticians (sociologists or economists). Inadequate methodologies and poor indices can affect the reputation of the interdisciplinary field too.

${ }^{32}$ Setting levels of measurement is in itself problematic: do we use nominal, ordinal, interval or ratio measure? See (Babbie 2013, 180-84) 155--158.

${ }^{33}$ E.g.: transforming a 0-1 scale into 0-100 means that 1 will be 100 , a $0-4$ scale into $0-100$ means that the value of 1 will be 25,2 is equal to 50,3 is 75 and 4 is 100 . Another possible method is the standardisation, i.e. the rescaling of variables in order to obtain a zero mean and a standard deviation of one.

34 (Saisana and Saltelli 2011)251.

35 (Saisana and Saltelli 2011) 252.
} 
more than $5 \%$, we use imputation. ${ }^{36}$ If, for example, an expert answered only 24 of the 25 questions, we can deduce her or his $25^{\text {th }}$, imputed answer from the other questions given by the expert in question. Or we can use the mean of the answers of the other experts, eventually belonging to the same cluster (based on the similar answers). We can use another, more complicated statistical methods too, every method has different advantage and inconvenience, but we can reduce the bias of the outcomes based on these methods.

We have to examine separately the non-arbitrary selection of the indicators, on which the indices are based. ${ }^{37}$ Indices based on many but bad indicators are called "indicator rich but information poor". ${ }^{38} \mathrm{We}$ can test this issue by using multivariate analysis. We examine the relation between the indicators, and the impact of them on the final outcome. We always have to test the influence of the individual variables on the final results (i.e. examine robustness). ${ }^{39}$

We also have to treat outliers, i.e. observations distant from other observations. In many cases, these are results of a measurement error. Here too, we can use several statistical methods to handle this problem: we can simply delete the values, use imputation techniques, or introduce natural logarithm, for example, to increase goodness of fit. Of course, there are some real outliers too. We have to take them into consideration in the model.

Weighting is an important question too. We can sum up the data with the same weight, but some characteristics are more important than others (for instance, concerning rule of law, it is more important that the police cannot shoot innocent civilians arbitrarily than is the duration of a procedure), ${ }^{40}$ On the other hand, it is not easy to find an objective method for weighting (because of the lack of knowledge, and therefore, because of the lack of experts' consensus). ${ }^{41}$ Testing indices without weight, using multivariate analysis, we can only change them by adding or deleting indicators. In the case of weighted indicators, we can change the weight too, without deleting the indicator. The underlying method of weighting must be clear and explicit too. ${ }^{42}$ In several cases, weighting can be implicit too: if for instance, we build in strongly correlated indicators into the index, it means also the weighting of the given question.

Instead of weighting, but in order to lower the impact of extreme values on the final index (considering the example above: in order to avoid the overscoring legal systems where the police can kill innocent people, but where other institutions are working well), we can use a geometric mean instead of an arithmetic mean. This permits a better comparability, i.e. the state with the arbitrary police but with a good performance on other scales will not perform better than a similar (slightly underperforming) state without such an extreme value. ${ }^{43}$ Instead of using means, we can also use factor analysis, but the description of this method is beyond the framework of the present study. ${ }^{44}$

We can also build sub-indices from indicators. This is useful because 1) it can diminish misunderstandings and biases, occurring in the case of using isolated indicators, 2) and we can measure the complex and multi-faceted characteristic of the institutional functions. ${ }^{45} \mathrm{We}$ can build dimensions from sub-indices. These are on a higher level of abstraction than the indicators, but on a

\footnotetext{
${ }^{36}$ see(Little and Rubin 2002) on filling in for missing values.

${ }^{37} \mathrm{On}$ this topic, see in detail e.g. about the democracy-indices (Müller and Pickel 2007)511--539.

38 (European Commission, Organisation for Economic Co-operation and Development, and SourceOECD (Online service) 2008)25.

${ }^{39}$ The multivariate analysis, mentioned earlier shows the inner correlation structure of the indicators. Analysing robustness on the contrary shows the impact of the indicators and methodological choices (normalisation, weighting) on the index.

${ }^{40}$ As an example of a weighted index of the rule of law see for example (Tai 2007)1--19.

41 (Saisana and Saltelli 2011) 254. wrote on the subjective character of weighting. Also sceptical toward weighting: (United Nations et al. 2011) 5. On the methods of weighting, see (European Commission, Organisation for Economic Co-operation and Development, and SourceOECD (Online service) 2008)31-33. and (Sharpe and Andrews 2012)An example of an index without weights is the Islamic Constitutions Index (Ahmed and Gouda 2015) 1-74.

42 (Saisana and Saltelli 2011)255.

43 (Saisana and Saltelli 2011) 256. Instead of taking the sum of the values and dividing it by the number of numbers (arithmetic average), we take the nth root of the product of $n$ numbers (geometric average).

${ }^{44}$ See in details (Rosenthal and Voeten 2007)711-728.

45 (United Nations et al. 2011).) 3.
} 
lower level compared to the final index: for example, in the case of Rule of Law, the working of the justice, or that of the police. We also can statistically test the relation between the dimensions, also in order to measure the impacts on the final index. Here we can use factor analysis as well or principal component analysis or Cronbach's alpha test. ${ }^{46}$ Thereafter we can correct the list of indicators, or the weights and the classifications into sub-indices (so that they measure similar but not identical things, with an existent but not full correlation). While building up the final index, we have to allow for the possibility of decomposition too, so that we can deduce from it the basic data and indicators. ${ }^{47}$

\subsection{Presenting, interpreting and comparing results}

The results are better represented in charts, but textual information is also needed for their interpretation. We have to keep in mind that the numbers in themselves can only represent correlation. ${ }^{48}$ In order to establish a causal relation on the basis of this, the content needs to be considered further.

Visualisation of the results with graphs, for example, can be spectacular, too. These can influence (or manipulate) interpretation and understanding, too. ${ }^{49}$ The results of an analysis extended on multiple countries can be represented on a map, or the countries can be classified into clusters.

If there are other indices on the same question, we should compare them with our own index, and we should explain the differences (low correlation), too. A very good summary of the different traditions of validation in comparative research on measuring democracy is given by Seawright and Collier. The presentation of the four great directions distinguished by the authors (i.e. levels of measurement, structural equation modelling with latent variables, pragmatic approach and case based approach) exceed the framework of this study. ${ }^{50}$

\section{International Indices on rule of Law Compared to the EU Justice Scoreboard}

Here, we present four internationally recognized indices on legal systems compared to the EU Justice Scoreboard. These are the indices of the Freedom House ("Freedom in the World", FIW), the Bertelsmann Stiftung ("Bertelsmann Transformation Index", BTI), the World Bank ("Worldwide Governance Indicators”, WGI), and the World Justice Project („Rule of Law Index”, WJP RLI). ${ }^{51}$ In order to give a clear-cut picture, we represent the similarities and differences in a chart. ${ }^{52}$ In the four indices, we also present the measurement of the Rule of Law, in order to point out the differences of conceptualization.

\footnotetext{
${ }^{46}$ See (European Commission, Organisation for Economic Co-operation and Development, and SourceOECD (Online service) 2008) 25--27, 63--82.

47 (European Commission, Organisation for Economic Co-operation and Development, and SourceOECD (Online service) 2008)16.

${ }^{48}$ A well-known example ad absurdum on the difference between strong correlation and causality: according to the superstition, the presence of storks can boost fertility. This belief seems to be confirmed by the data: childbirth is correlated with the number of storks in a given region. In fact, in urbanised regions, the huntingground of storks are very limited. Parallel to this, in urban, industrialised regions, the birth rate used to be lower than in rural regions. So there is no causality between the number of storks and number of new-born babies. (Babbie 2013, 94, 442-49)483-484.

${ }^{49}$ See further for example: (Telea 2015); (Ballstaedt 2012).

${ }^{50}$ (Seawright and Collier 2014 especially Table I. on page 113.)

${ }^{51}$ For the former tree, a good overview is given by (Thiery, Shering, and Muno 2009). About Freedom House recently: (Bradley 2015) 27-74; on the Rule of Law Index: (Urueña 2015) 75--102; and (Restrepo Amariles 2014)193--234. For a methodological and comparative analysis of the WGI, see: (Gisselquist 2015) 23 - 54.

${ }^{52}$ The chart is based on the following literature: for the first three indices: (Skaaning 2010) 449-460; (Nardulli, Peyton, and Bajjalieh 2013)139--192; (Thiery, Shering, and Muno 2009); (Kaufmann, Kraay, and Mastruzzi 2011); and the websites of the indices. For WJP RLI: Developing Indicators to Measure the Rule of Law: A Global Approach. A Report for the World Justice Project, 2008 Vera Institute of Justice; (Botero and Ponce 2011) On the EU Justice Scoreboard, see: http://ec.europa.eu/justice/effective-justice/scoreboard/index_en.htm
} 


\begin{tabular}{|c|c|c|c|c|c|}
\hline & FIW & BTI & WGI & WJP RLI & EU Justice Scoreboard \\
\hline $\begin{array}{l}\text { Goals (Measured } \\
\text { values?) }\end{array}$ & $\begin{array}{l}\text { Global comparative } \\
\text { evaluation of } \\
\text { political rights and } \\
\text { civil liberties }\end{array}$ & $\begin{array}{l}\text { Evaluates and measures the steps of } \\
\text { developing and transition countries } \\
\text { (Entwicklungs- und } \\
\text { Transformationsländer) toward } \\
\text { democracy and market economy }\end{array}$ & $\begin{array}{l}\text { Aggregate and individual } \\
\text { governance indicators }\end{array}$ & $\begin{array}{l}\text { Measurement of the de facto } \\
\text { rule of law, (based on the } \\
\text { people's experience, not on } \\
\text { the legal rules) }\end{array}$ & $\begin{array}{l}\text { Measuring quality, efficiency and } \\
\text { independence of justice in the } \\
\text { Member States of the EU }\end{array}$ \\
\hline $\begin{array}{l}\text { How long and } \\
\text { how frequently? }\end{array}$ & $\begin{array}{l}\text { Yearly since } 1972 \\
195 \text { countries today } \\
\text { ( }+15 \text { disputed or } \\
\text { special territories). }\end{array}$ & $\begin{array}{l}\text { Since } 2006 \text { two-yearly (a pilot study } \\
\text { in } 2003 \text { ) today } 129 \text { developing and } \\
\text { transition countries (i.e., every non- } \\
\text { member countries of the OECD in } \\
1989 \text {, provided that the population is } \\
\text { over } 2 \text { millions) }\end{array}$ & $\begin{array}{l}\text { Since } 1996, \text { yearly since } 2002 \text { on } \\
215 \text { economies at the present time. }\end{array}$ & $\begin{array}{l}\text { Yearly since } 2011 \text { (in } \\
2012 / 13 \text {, a unified biannual } \\
\text { report), in } 102 \text { countries }\end{array}$ & $\begin{array}{l}\text { Yearly since } 2013 \text { in all the } \\
\text { Member States of the EU) }\end{array}$ \\
\hline Conceptualisation & $\begin{array}{l}\text { Political rights: } \\
\text { (1) Electoral process } \\
\text { (2) political pluralism } \\
\text { and participation, } \\
\text { (3) Functioning of } \\
\text { Government. } \\
\text { Civil Liberties: } \\
\text { (1) Freedom of } \\
\text { Expression and } \\
\text { Belief } \\
\text { (2) Associational and } \\
\text { Organizational Rights } \\
\text { (3) Rule of law [in } \\
\text { common sense with } \\
\text { somehow arbitrary } \\
\text { elements], } \\
\text { (4) Personal } \\
\text { Autonomy and } \\
\text { Individual Rights } \\
\text { There are four } \\
\text { questions on rule of } \\
\text { law: }\end{array}$ & $\begin{array}{l}\text { The final index (Status Index) is } \\
\text { composed of a democracy and } \\
\text { market economy part } \\
\text { The Democracy Index is based on } \\
\text { an explicit and philosophically } \\
\text { elaborate democracy-concept: } \\
\text { (1) Stateness } \\
\text { (2) Political participation } \\
\text { (3) Rule of law } \\
\text { (4) Stability of democratic } \\
\text { institutions } \\
\text { (5) Political and Social Integration } \\
\text { The four constituents of Rule of } \\
\text { Law are partially overlapping, } \\
\text { according to the traditional legal } \\
\text { doctrine : } \\
\text { (1) Separation of powers, } \\
\text { (2) Independent judiciary } \\
\text { (3) Prosecution of office abuse, } \\
\text { (4) Civil rights }\end{array}$ & $\begin{array}{l}\text { for six dimensions of governance: } \\
\text { (1) Voice and Accountability } \\
\text { (2) Political Stability and Absence } \\
\text { of Violence } \\
\text { (3) Government Effectiveness } \\
\text { (4) Regulatory Quality } \\
\text { (5) Rule of law } \\
\text { (6) Control of Corruption } \\
\text { "Rule of law captures perceptions } \\
\text { of the extent to which agents have } \\
\text { confidence in and abide by the } \\
\text { rules of society, and in particular } \\
\text { the quality of contract } \\
\text { enforcement, property rights, the } \\
\text { police, and the courts, as well as } \\
\text { the likelihood of crime and } \\
\text { violence." } \\
\text { Conceptualisation is problematic, }{ }^{55} \\
\text { rather formal than substantial } \\
\text { criteria. } \\
\text { Measuring rule of law on the basis }\end{array}$ & $\begin{array}{l}\text { Based mainly on UN- } \\
\text { documents, the definition of } \\
\text { the rule of law is a system } \\
\text { relying on the following four } \\
\text { principles: } \\
\text { "(1) The government and its } \\
\text { officials and agents as well } \\
\text { as individuals and private } \\
\text { entities are accountable } \\
\text { under the law. } \\
\text { (2) The laws are clear, } \\
\text { publicized, stable, and just; } \\
\text { are applied evenly; and } \\
\text { protect fundamental rights, } \\
\text { including the security of } \\
\text { persons and property and } \\
\text { certain core human rights. } \\
\text { (3) The process by which the } \\
\text { laws are enacted, } \\
\text { administered, and enforced is } \\
\text { accessible, fair, and efficient. } \\
\text { (4) Justice is delivered } \\
\text { timely by competent, ethical, } \\
\text { and independent }\end{array}$ & $\begin{array}{l}\text { I. Efficiency of justice systems } \\
\text { 1.Length of proceedings } \\
\text { 2.Clearance rate } \\
\text { 3.Pending cases } \\
\text { 4.Efficiency in specific areas } \\
\text { II. Quality of justice systems } \\
\text { 1.Accessibility } \\
\text { 2.Resources } \\
\text { 3.Assessment tools } \\
\text { 4.Quality standards } \\
\text { III. Independence } \\
\text { 1.Perceived judicial independence } \\
\text { 2.Structural independence } \\
\text { 3. Work of the judicial networks } \\
\text { on judicial independence } 44\end{array}$ \\
\hline
\end{tabular}

${ }^{53}$ According to (Thiery, Shering, and Muno 2009) 154. the correlation between FIW and BTI is very high $(0,938)$, but the WGI correlates with the FIW and BTI only by 0,664 and 0,663 respectively this might signal that the WGI is measuring something else than the another two.

${ }_{54}^{54} \mathrm{http}$ ://info.worldbank.org/governance/wgi/rl.pdf

${ }^{55}$ Especially critically (Ginsburg 2011) 271. 


\begin{tabular}{|c|c|c|c|c|c|}
\hline & $\begin{array}{l}\text { (1) Is there an } \\
\text { independent } \\
\text { judiciary? } \\
\text { (2) Does the rule of } \\
\text { law prevail in civil } \\
\text { and criminal matters? } \\
\text { Are police under } \\
\text { direct civilian } \\
\text { control? } \\
\text { (3) Is there protection } \\
\text { from political terror, } \\
\text { unjustified } \\
\text { imprisonment, exile, } \\
\text { or torture, whether by } \\
\text { groups that support or } \\
\text { oppose the system? Is } \\
\text { there freedom from } \\
\text { war and } \\
\text { insurgencies? } \\
\text { (4) Do laws, policies, } \\
\text { and practices } \\
\text { guarantee equal } \\
\text { treatment of various } \\
\text { segments of the } \\
\text { population? }\end{array}$ & & $\begin{array}{l}\text { of } 23 \text { sources (including the partial } \\
\text { indices - and not the main indices - } \\
\text { of BTI, FIW, WJP.) using } 86 \text { data } \\
\text { units ( } 44 \text { of them are } \\
\text { representative, } 42 \text { are not" } \\
\text { Representative indicators are } \\
\text { indicators that cover a set of } \\
\text { countries in which the distribution } \\
\text { of governance is likely to be } \\
\text { similar to that in the world as a } \\
\text { whole.[...] In contrast non- } \\
\text { representative indicators cover } \\
\text { either specific regions (for example } \\
\text { the BEEPS survey of transition } \\
\text { economies or the LatinoBarometer } \\
\text { survey of Latin American } \\
\text { countries), or particular income } \\
\text { levels (for example the World } \\
\text { Bank CPIA ratings that cover only } \\
\text { developing countries)."56 }\end{array}$ & $\begin{array}{l}\text { representatives and neutrals } \\
\text { who are of sufficient } \\
\text { number, have adequate } \\
\text { resources, and reflect the } \\
\text { makeup of the communities } \\
\text { they serve."57 } \\
\text { According to the principles } \\
\text { above, they measure } 9 \\
\text { factors and } 47 \text { sub-factors: } \\
\text { (1) Constraints on } \\
\text { Government Powers } \\
\text { (2) Absence of Corruption } \\
\text { (3) Open Government } \\
\text { (4) Fundamental Rights } \\
\text { (5) Order and Security } \\
\text { (6) Regulatory Enforcement } \\
\text { (7) Civil Justice } \\
\text { (8) Criminal Justice } \\
\text { (9) Informal Justice } \\
\text { (i.e. traditional, tribal, and } \\
\text { religious courts) } \\
\text { 58 }\end{array}$ & \\
\hline Selecting data & $\begin{array}{l}\text { Expert's opinions } \\
\text { evaluating with } \\
\text { points ranging from } 1 \\
\text { to } 7 \text {, a general } \\
\text { codebook with the } \\
\text { definition of the } \\
\text { grades only, not that } \\
\text { of the individual } \\
\text { questions. } \\
\text { The list of experts is }\end{array}$ & $\begin{array}{l}\text { Mainly based on expert's opinion, } \\
\text { with a standardised codebook. } \\
\text { Points ranging from } 1 \text { to } 10 \text { (with } \\
\text { separate instructions for every single } \\
\text { question). Not only numbers but a } \\
\text { descriptive text (two reports on a } \\
\text { country: a foreign and a domestic } \\
\text { report, the latter commenting the } \\
\text { former too); the list of experts is } \\
\text { public, but intransparent }\end{array}$ & $\begin{array}{l}\text { Based on several hundreds of } \\
\text { indicators from } 32 \text { different } \\
\text { sources. }\end{array}$ & $\begin{array}{l}\text { So-called General Population } \\
\text { Polls: } 1000 \text { respondents from } \\
\text { the three largest cities of the } \\
\text { country, selected by } \\
\text { probability sampling. } \\
\text { + Qualified Respondents' } \\
\text { Questionnaires: } 25 \text { legal } \\
\text { professionals/country in } \\
\text { average (the scores from the } \\
\text { two types of Questionnaire - } \\
\text { when available - were }\end{array}$ & $\begin{array}{l}\text { Most of the data is acquired from } \\
\text { the Council of Europe } \\
\text { Commission for the Evaluation of } \\
\text { the Efficiency of Justice (CEPEJ), } \\
\text { other sources are contact persons } \\
\text { on national justice systems ( } 2 \text { ), } \\
\text { the European Network of } \\
\text { Councils for the Judiciary } \\
\text { (ENCJ), the Network of the } \\
\text { Presidents of the Supreme Judicial }\end{array}$ \\
\hline
\end{tabular}

${ }_{57}^{56}$ (Kaufmann, Kraay, and Mastruzzi 2011, 243)

${ }_{58} \mathrm{http}$ ://worldjusticeproject.org/what-rule-law

58 They also collect data on the 9th factor (Informal Justice) but they do not take into consideration in the aggregate index and in the ranking. These systems are especially complicated, and it is not too easy to measure comparably the efficiency and fairness in these cases. Therefore, the aggregate index is made up of 8 factors and 44 sub-factors "only". 


\begin{tabular}{|c|c|c|c|c|c|}
\hline & $\begin{array}{l}\text { not public, the } \\
\text { selection is not } \\
\text { transparent. } \\
\text { Measuring } 27 \\
\text { questions in } 8 \text { groups }\end{array}$ & $\begin{array}{l}\text { hard data too (on inflation and } \\
\text { education). } \\
17 \text { criteria with } 49 \text { questions. }\end{array}$ & & $\begin{array}{l}\text { weighted } 50 \%-50 \%) \\
\text { Selecting experts: two } \\
\text { methods: } \\
\text { (1) random sampling from a } \\
\text { list of experts like law } \\
\text { professors, attorneys, NGO } \\
\text { professionals etc. } \\
\text { (2) WJP network of } \\
\text { practitioners and academics }\end{array}$ & $\begin{array}{l}\text { Courts of the EU, Association of } \\
\text { the Councils of State and Supreme } \\
\text { Administrative Jurisdictions of the } \\
\text { EU (ACA), the European } \\
\text { Competition Network, the } \\
\text { Council of Bars and Law } \\
\text { Societies of Europe (CCBE), the } \\
\text { Communications Committee, the } \\
\text { European Observatory on } \\
\text { infringements of intellectual } \\
\text { property rights, the Consumer } \\
\text { Protection Cooperation Network, } \\
\text { Eurostat, the European Judicial } \\
\text { Training Network (EJTN), the } \\
\text { World Bank and the World } \\
\text { Economic Forum. }\end{array}$ \\
\hline $\begin{array}{l}\text { Methods of } \\
\text { aggregation }\end{array}$ & arithmetic mean & arithmetic mean & $\begin{array}{l}\text { Aggregation in three steps: } \\
\text { (1) Each question of the original } \\
\text { source is assigned to one of the six } \\
\text { indicators } \\
\text { (2) Questions of the original } \\
\text { sources are rescaled between } 0 \text { and } \\
1,1 \text { meaning the best outcome } \\
\text { (3) Constructing a weighted } \\
\text { average using an Unobserved } \\
\text { Components Model }\end{array}$ & $\begin{array}{l}\text { Aggregation in five steps } \\
\text { (1) Translating the } \\
\text { questionnaire into numbers } \\
\text { (2) Raw country scores } \\
\text { aggregated from the } \\
\text { individuals (experts or } \\
\text { general public) } \\
\text { (3) Normalising the raw } \\
\text { data. } \\
\text { (4) Aggregating normalized } \\
\text { data into factors and sub- } \\
\text { factors using simple average } \\
\text { (5) Final ranking of the } \\
\text { countries. }\end{array}$ & $\begin{array}{l}\text { No final overall composite index, } \\
\text { part-indices and indicators only }\end{array}$ \\
\hline $\begin{array}{l}\text { Degree of } \\
\text { transparency }\end{array}$ & $\begin{array}{l}\text { Low but progressing } \\
\text { (not every data are } \\
\text { available on the } \\
\text { website, the sub- } \\
\text { indices of the rule of } \\
\text { law are also } \\
\text { inaccessible) }\end{array}$ & $\begin{array}{l}\text { High (all data used is available on } \\
\text { the website, with the related part of } \\
\text { the country-report). }\end{array}$ & $\begin{array}{l}\text { Very elaborate calculations, but } \\
\text { inherits the intransparency of the } \\
\text { sources. }\end{array}$ & high & High: relatively simple indices \\
\hline Strength & $\begin{array}{l}\text { (1) Data available } \\
\text { since } 1972 \\
\text { (2) Well-known } \\
\text { trademark }\end{array}$ & $\begin{array}{l}\text { (1) Transparency } \\
\text { (2) The controlling function of the } \\
\text { second report } \\
\text { (3) Better conceptualisation } \\
\text { compared to the FIW } \\
\text { (4) As a last step an expert }\end{array}$ & $\begin{array}{l}\text { (1) Elaborate mathematical model } \\
\text { (2) Robust (the change of a single } \\
\text { indicator do not impact deeply the } \\
\text { whole). }\end{array}$ & $\begin{array}{l}\text { Also focusing on the } \\
\text { perception of rule of law in } \\
\text { vulnerable groups (like the } \\
\text { low-income groups) } \\
\text { The choosing of experts is }\end{array}$ & $\begin{array}{l}\text { Mainly basic, easily quantifiable } \\
\text { data }\end{array}$ \\
\hline
\end{tabular}




\begin{tabular}{|c|c|c|c|c|c|}
\hline & & $\begin{array}{l}\text { committee corrects the data } \\
\text { regionally and globally for the better } \\
\text { international comparison }\end{array}$ & & transparent & \\
\hline $\begin{array}{l}\text { Shortcomings and } \\
\text { critics }\end{array}$ & $\begin{array}{l}\text { (1) Geometric mean } \\
\text { would be better here } \\
\text { than arithmetic mean } \\
\text { (2) lack of } \\
\text { transparency (coding } \\
\text { below the sub- } \\
\text { categories remains } \\
\text { not transparent), } \\
\text { (3) the differences } \\
\text { between the grades of } \\
\text { the } 1-7 \text { are unclear } \\
\text { (4) lack of } \\
\text { consistency in time: } \\
\text { changing questions } \\
\text { (5) the borders } \\
\text { between the } \\
\text { dimensions are } \\
\text { unclear } \\
\text { (6) Selection of } \\
\text { experts is not } \\
\text { transparent }\end{array}$ & $\begin{array}{l}\text { (1) Geometric mean would be better } \\
\text { here than arithmetic mean } \\
\text { (2) Not transparent selection criteria } \\
\text { of the experts. } \\
\text { (3) The Status Index implies that the } \\
\text { political and economic development } \\
\text { are strongly correlated, which is not } \\
\text { necessarily true (see China). }\end{array}$ & $\begin{array}{l}\text { (1) Inheriting the shortcomings of } \\
\text { the original sources } \\
\text { (2) Market-economy -oriented, } \\
\text { because of the numerous market- } \\
\text { indicators. } \\
\text { (3) Difficult comparison in time } \\
\text { and between countries as the } \\
\text { sources are constantly changing. } \\
\text { (4) Weak conceptualisation; } \\
\text { (5) No text, only numbers. }\end{array}$ & $\begin{array}{l}\text { (1) No text, numbers only } \\
\text { (except one paragraph } \\
\text { interpreting the results in the } \\
\text { last version) } \\
\text { (2) The Constraints on } \\
\text { Government Powers sub- } \\
\text { index is centred on } \\
\text { presidential systems. }\end{array}$ & $\begin{array}{l}\text { No final aggregate index, } \\
\text { changing methodology, from our } \\
\text { point of view, the main goal of the } \\
\text { indices is to measure quality, } \\
\text { efficiency and independence of } \\
\text { justice in the Member States of } \\
\text { the EU, and not the rule of law in } \\
\text { general. }\end{array}$ \\
\hline $\begin{array}{l}\text { General } \\
\text { evaluation of the } \\
\text { index }\end{array}$ & $\begin{array}{l}\text { Old methodology and } \\
\text { lack of transparency. }\end{array}$ & $\begin{array}{l}\text { Developed methodology, } \\
\text { transparent and global index with a } \\
\text { part focusing on the rule of law }\end{array}$ & $\begin{array}{l}\text { The method minimalizes the } \\
\text { subjective elements (except for the } \\
\text { choosing of indicators) the main } \\
\text { focus is not the rule of law }\end{array}$ & $\begin{array}{l}\text { Very elaborate methodology, } \\
\text { focusing on the aspects of } \\
\text { the rule of law }\end{array}$ & $\begin{array}{l}\text { The EU Justice Scoreboard is } \\
\text { different to the other indices } \\
\text { enlisted here, as it is closer to } \\
\text { classical judiciary statistics. }\end{array}$ \\
\hline
\end{tabular}


In the former chapters, we presented the difficulties of the construction of indices measuring the rule of law. First of all, these indices are used by academics, even if the unanticipated shifts in these indices are covered by the press. ${ }^{59}$ Some of the numerical data is also taken into consideration by investors. The proposals described above in the Introduction go beyond this: they want to link a sanction or a procedure to a given level of measurement. Sanctions based on numbers are of course not new in constitutional or European law. Consider, for example, the budgetary constraints (i.e.: deficit brakes, debt brakes and expenditure brakes) in several Constitutions, ${ }^{60}$ or the Maastricht criteria and the regulation of the budgetary balance on the EU-level. ${ }^{61}$ For the first sight, they may serve as a model for the procedure and sanction based on the rule of law indices. Budgetary rules and fiscal policy are perceived by the market, therefore clear and simple signals are needed. The transgression of the determined numbers should activate almost automatically a procedure reaching a sanction at the end. Meanwhile, as Adamski pointed out, despite the seemingly clean-cut rules, the authorities are not always consequent. ${ }^{62}$

In our case, we should first determine the methodology and the EU authorities responsible for the construction of the index. The indices presented above are constructed mostly independently from the European Union, this means independence to some extent, but if we would like to link some sanctions to these indices, we cannot outsource them. On the other hand, the construction of such indices can take years. As we have seen above, there is a constant adjustment of the methodology during the years. A new index should be tested during numerous periods in order to obtain a credible tool. A further question is the discretional power of the authority supervising the compliance of the states. In the case of budgetary question, the competence of an already existing body is questionable. ${ }^{63}$ Even if the transgression of the given limit is clear, the necessary measures are complicated. ${ }^{64}$ It is doubly so in the case of the rule of law: while in the case of excess deficit, a given body can simply examine whether the budget of next year projects better figures, underperformance in the field of rule of law can have numerous origins. And in the budget, you can regroup or diminish some sums, but in the case of the rule of law, the different factors are not substitutable.

${ }^{61}$ (Adamski 2013)

${ }^{62}$ (Adamski 2013, 52-63)

${ }^{63}$ On the level of the State, we can for example question the competence of an ordinary Constitutional Court (Jakab 2016, 25-26)

${ }^{64}$ In the case of budgetary imbalance, painful structural reforms are also needed (Adamski 2013, 56) 
Bibliography

Adamski, Dariusz. 2013. "Europe's (Misguided) Constitution of Economic Prosperity." Common Market Law Review 50 (1): 47-85.

Ahmed, Dawood I., and Moamen Gouda. 2015. "Measuring Constitutional Islamization: The Islamic Constitutions Index." Hastings International and Comparative Law Review 38 (1). http://papers.ssrn.com/abstract=2523337.

Babbie, Earl R. 2013. The Practice of Social Research. Thirteenth edition. Belmont, Calif: Wadsworth Cengage Learning.

Ballstaedt, Steffen-Peter. 2012. Visualisieren: Bilder in wissenschaftlichen Texten. UTB Schlüsselkompetenzen 3508. Konstanz: UVK Verl.-Ges.

Bárd, Petra, Sergio Carrera, Elspeth Guild, and Dimitry Kochenov. 2016. “An EU Mechanism on Democracy, the Rule of Law, and Fundamental Rights: Assessing the Need and Possibilities for the Establishment of an EU Scoreboard on Democracy, the Rule of Law and Fundamental Rights." European Parliament, Research Paper, no. PE 579328.

Blank, Jos. 2004. Bench Marking in an International Perspective: An International Comparison of the Mechanisms and Performance of the Judiciary System. Rotterdam: ECORYS-NEI, Labour \& Social Policy.

Bogdandy, Armin von, and Matthias Goldmann. 2008. "The Exercise of International Public Authority through National Policy Assessment: The OECD\&apos;s PISA Policy as a Paradigm for a New International Standard Instrument." International Organizations Law Review 5 (2): 241-98. doi:10.1163/157237408X412907.

Botero, Juan Carlos, Robert L. Nelson, and Christine Pratt. 2011. "Indices and Indicators of Justice, Governance, and the Rule of Law: An Overview." Hague Journal on the Rule of Law 3 (2): 153-169. doi:10.1017/S1876404511200010.

Botero, Juan Carlos, and Alejandro Ponce. 2011. "Measuring the Rule of Law." SSRN Scholarly Paper ID 1966257. Rochester, NY: Social Science Research Network. http://papers.ssrn.com/abstract=1966257.

Bradley, Christopher G. 2015. "International Organizations and the Production of Indicators: The Case of Freedom House." In The Quiet Power of Indicators. Cambridge Studies in Law and Society. Cambridge University Press. http://dx.doi.org/10.1017/СВ09781139871532.002.

Cherchye, Laurens, C. A. Knox Lovell, Wim Moesen, and Tom Van Puyenbroeck. 2007. "One Market, One Number? A Composite Indicator Assessment of EU Internal Market Dynamics." European Economic Review 51 (3): 749-79. doi:10.1016/j.euroecorev.2006.03.011.

Davis, Kevin E., Benedict Kingsbury, and Sally Engle Merry. 2012. "Indicators as a Technology of Global Governance." Law \& Society Review 46 (1): 71-104. doi:10.1111/j.15405893.2012.00473.x.

Desrosières, Alain. 2015. "Retroaction: How Indicators Feed Back onto Quantified Actors." In The World of Indicators. Cambridge Studies in Law and Society. Cambridge University Press. http://dx.doi.org/10.1017/СBO9781316091265.013.

European Commission, Organisation for Economic Co-operation and Development, and SourceOECD (Online service), eds. 2008. Handbook on Constructing Composite Indicators: Methodology and User Guide. Paris: OECD.

Fauvarque-Cosson, Bénédicte, and Anne-Julie Kerhuel. 2009. "Is Law an Economic Contest? French Reactions to the Doing Business World Bank Reports and Economic Analysis of the Law." American Journal of Comparative Law 57 (4): 811-29. doi:10.5131/ajcl.2008.0024.

Fukuda-Parr, Sakiko, Terra Lawson-Remer, and Susan Randolph. 2015. Fulfilling Social and Economic Rights. New York: Oxford University Press.

Gajduschek, György. 2014. "Miben Áll, És Mérhetö-E a Kormányzati Teljesítmény? [What Is It and How to Measure Government Performance?]." Politikatudományi Szemle, no. 3: 97-116.

Ginsburg, Tom. 2011. "Pitfalls of Measuring the Rule of Law." Hague Journal on the Rule of Law 3 (2): 269-280. doi:10.1017/S187640451120006X. 
Gisselquist, Rachel M. 2015. "Evaluating Governance Indexes: Key Criteria." In On Governance: What It Is, What It Measures and Its Policy Uses, edited by Robert I. Rotberg, 23-54. Waterloo, ON: CIGI.

Hammergren, Linn. 2015. "Indices, Indicators and Statistics: A View from the Project Side as to Their Utility and Pitfalls." Hague Journal on the Rule of Law 3 (2): 305-16. doi:10.1017/S1876404511200083.

Jakab, András. 2016. "Sustainability in European Constitutional Law." Max Planck Institute for Comparative Public Law \& International Law (MPIL) Research Paper, no. 16: 1-27.

Kaplan, Abraham. 1964. The Conduct of Inquiry; Methodology for Behavioral Science. Chandler Publications in Anthropology and Sociology. San Francisco: Chandler Pub. Co.

Kaufmann, Daniel, Aart Kraay, and Massimo Mastruzzi. 2011. "The Worldwide Governance Indicators: Methodology and Analytical Issues." Hague Journal on the Rule of Law 3 (2): 220246. doi:10.1017/S1876404511200046.

Krever, Tor. 2013. "Quantifying Law: Legal Indicator Projects and the Reproduction of Neoliberal Common Sense." Third World Quarterly 34 (1): 131-50. doi:10.1080/01436597.2012.755014.

Little, Roderick J. A., and Donald B. Rubin. 2002. Statistical Analysis with Missing Data. 2nd ed. Wiley Series in Probability and Statistics. Hoboken, N.J: Wiley.

Merry, Sally Engle, Kevin E. Davis, and Benedict Kingsbury, eds. 2015. The Quiet Power of Indicators: Measuring Governance, Corruption, and the Rule of Law. Cambridge Studies in Law and Society. New York, NY: Cambridge University Press.

Michaels, Ralf. 2009. "Comparative Law by Numbers? Legal Origins Thesis, Doing Business Reports, and the Silence of Traditional Comparative Law." American Journal of Comparative Law, January, 765-95.

Müller, Thomas, and Susanne Pickel. 2007. "Wie lässt sich Demokratie am besten messen? Zur Konzeptqualität von Demokratie-Indizes." Politische Vierteljahresschrift 48 (3): 511-39. doi:10.1007/s11615-007-0089-3.

Nardulli, Peter F., Buddy Peyton, and Joseph Bajjalieh. 2013. "Conceptualizing and Measuring Rule of Law Constructs, 1850-2010." Journal of Law and Courts 1 (1): 139-92. doi:10.1086/668543.

Parsons, Jim. 2011. "Developing Clusters of Indicators: An Alternative Approach to Measuring the Provision of Justice." Hague Journal on the Rule of Law 3 (2): 170-185. doi:10.1017/S1876404511200022.

Porter, Theodore M. 2015. "The Flight of the Indicator." In The World of Indicators. Cambridge Studies in Law and Society. Cambridge University Press. http://dx.doi.org/10.1017/CBO9781316091265.002.

Restrepo Amariles, David. 2014. “The Mathematical Turn: L'indicateur Rule of Law Dans La Politique de Développement de La Banque Mondiale." In Gouverner Par Les Standards et Les Indicateurs: De Hume Au Rankings, edited by Benoit Frydman and Arnaud Van Waeyenberge. Bruylant: Brussels.

Rosenthal, Howard, and Erik Voeten. 2007. "Measuring Legal Systems." Journal of Comparative Economics 35 (4): 711-28. doi:10.1016/j.jce.2007.08.001.

Rosga, AnnJanette, and Margaret Satterthwaie. 2009. "The Trust in Indicators: Measuring Human Rights." Berkeley Journal of International Law 27 (2): 253. doi:doi:10.15779/Z38G07R.

Rottenburg, Richard, ed. 2015. The World of Indicators: The Making of Governmental Knowledge through Quantification. Cambridge, United Kingdom: Cambridge University Press.

Saisana, Michaela, and Andrea Saltelli. 2011. "Rankings and Ratings: Instructions for Use." Hague Journal on the Rule of Law 3 (2): 247-268. doi:10.1017/S1876404511200058.

Saltelli, Andrea. 2006. "Composite Indicators between Analysis and Advocacy." Social Indicators Research 81 (1): 65-77. doi:10.1007/s11205-006-0024-9.

Seawright, Jason, and David Collier. 2014. "Rival Strategies of Validation Tools for Evaluating Measures of Democracy." Comparative Political Studies 47 (1): 111-38. doi:10.1177/0010414013489098. 
Sharpe, Andrew, and Brandon Andrews. 2012. "An Assessment of Weighting Methodologies for Composite Indicators: The Case of the Index of Economic Well-Being." CSLS Research Report, no. 10.

Skaaning, Svend-Erik. 2010. "Measuring the Rule of Law." Political Research Quarterly 63 (2): 44960.

Tai, Benny Y.T. 2007. "Developing an Index of the Rule of Law: Sharing the Experience of Hong Kong." Asian Journal of Comparative Law 2 (January): 1-19. doi:10.1017/S2194607800000041.

Telea, Alexandru. 2015. Data Visualization: Principles and Practice. Second edition. Boca Raton: CRC Press, Taylor \& Francis Group.

Thiery, Peter, Jenniver Shering, and Wolfgang Muno. 2009. "Wie Misst Man Recht? Möglichkeiten Und Grenzen Der Messung von Rechtsstaatlichkeit, Kongressbeiträge." In Interdisziplinäre Rechtsforschung: Kongressbeiträge "Wie Wirkt Recht", by Josef Estermann, 141-60. Bern: Stämpfli.

United Nations, Department of Peace-keeping Operations, United Nations, Office of the High Commissioner for Human Rights, Vera Institute of Justice, Altus Global Alliance, University of the Fraser Valley, and Harvard University. 2011. United Nations Rule of Law Indicators Implementation Guide and Project Tools. [New York]: United Nations. http://search.ebscohost.com/login.aspx?direct=true\&scope=site \&db=nlebk\&db=nlabk\&AN= 387576.

Urueña, René. 2015. "Indicators and the Law: A Case Study of the Rule of Law Index." In The Quiet Power of Indicators. Cambridge Studies in Law and Society. Cambridge University Press. http://dx.doi.org/10.1017/CBO9781139871532.003.

Versteeg, Mila, and Tom Ginsburg. 2016. "Measuring the Rule of Law: A Comparison of Indicators." Law \& Social Inquiry, January, n/a-n/a. doi:10.1111/Isi.12175. 
Cover: Imbalanced World, 1996, Veronika Dell‘Olio (photo: Miriam Aziz)

"Essential to our concept was the establishment of a connection to the work and objectives of the institute. In view of the diversity of the research tasks concerned, we have attempted to highlight an overarching idea that can be understood as the institute's mission. We see this as the ideal of peaceful relations between peoples on the basis of an internationally validated notion of justice.... The depicted sculpture...[symbolizes] an imbalanced world in which some peoples are oppressed while others lay claim to dominance and power. The honeycomb form of the circular disks denotes the [international] state structure. Glass parts ... [represent] the individual states .... [The division] of the figure ... into two parts [can] be interpreted as the separation of the earth into two unequal worlds. The scissors-shaped base, on the one hand, makes the gap between them clear, on the other hand, a converging movement of the disks is conceivable.... The sculpture [aims] at what is imagined - the possibility of the rapprochement of the two worlds." [transl. by S. Less]

Art in architecture, MPIL, Heidelberg

\section{MAX PLANCK INSTITUTE}

FOR COMPARATIVE PUBLIC LAW

AND INTERNATIONAL LAW

Im Neuenheimer Feld 535

D-69120 Heidelberg

Tel.: +49 (0)6221 $482-1$

Fax: $+49(0) 6221482-288$

www.mpil.de

SSRN@mpil.de 